\title{
MEETINGS OF THE BOARD OF CONSERVATION
}

'The list below shows the meetings of the State Board of Conservation during the time the Curator of the Historical Department was a member of that body, with the dates and places of meetings, and when the meetings were with the Executive Council.

Date

Place

December 27, 1918..... Office of Treasurer of State-With Executive Council.

January 1, $1919 . \ldots$. ...Grand Hotel, Council Bluffs.

February 12, 1919...... Office of Curator, Historical Department.

February 19, 1919...... On board train, Glenwood to Red Oak.

February 22, 1919...... Office of Treasurer of State-With Executive Council.

April 26, 1919......... Cedar Rapids.

July 12, $1919 \ldots \ldots \ldots$. Keosauqua.

July 19, $1919 \ldots \ldots \ldots$. Davenport.

July $21,1919 \ldots \ldots \ldots$. Tama.

July 28, 1919.........McGregor-With Executive Council.

August 30, 1919........ Office of Curator, Historical Department.

September 5, 1919...... Office of Curator, Historical Department.

September 19, 1919..... Fairfield.

October $5,1919 \ldots \ldots$. Office of Curator, Historical Department. October 17, 1919....... Office of Curator, Historical Department. November 15, 1919......Ames.

December 6, 1919...... Office of Curator, Historical Department. December 13, 1919...... Office of Curator,.Historical Department. January 23, $1920 \ldots \ldots$.... Fort Dodge.

February 6, 1920....... Office of Curator, Historical Department. February 7, 1920........ Office of Treasurer of State-With Executive Council.

March 5,1920........ Office of Curator, Historical Department. March 19, 1920......... Ames.

April $3,1920 \ldots \ldots \ldots \ldots$. Office of Curator, Historical Department. A pril 23, 1920.......... Towa City.

May 14, $1920 \ldots \ldots \ldots$. . . Spirit Lake.

May 21, 1920.......... Cedar Rapids.

May 28, 1920..........Lamont.

June 18, 1920......... La Crosse, Wisconsin.

July $10,1920 \ldots \ldots \ldots \ldots$. Traer.

July $16,1.920 \ldots \ldots \ldots$. Lake Okoboji.

July 28, $1920 \ldots \ldots \ldots$. Office of Curator, Historical Department. September 24, 1920..... Office of Curator, Historical Department. December 3, 1920...... Office of Curator, Historical Department. 
January 10, 1921........ Fort Des Moines Hotel.

January 28, 1921....... Office of Curator, Historical Department. February 16, 1921...... Office of Curator, Historical Department. April 22, 1921.......... Office of Curator, Historical Department. June 17, 1921.......... Office of Curator, Historical Department. June 18, 1921......... State House-With Executive Council.

July 19, 1921.......... Office of Curator, Historical Department. October 15, 1921........Adjoining room to Governor's office.

October 21, 1921........Anamosa.

April 25, 1922 .......... Office of Curator, Historical Department. May 9, 1922.......... Office of Curator, Historical Department. June 16, 1922.......... Office of Curator, Historical Department. July 14, $1922 \ldots \ldots \ldots$..... Boone.

July 21, 1922 .......... Office of Curator, Historical Department. A ugust 11, 1922........McGregor.

September 13,1922...... Office of Curator, Historical Department. October 13, 1922....... Strawberry Point.

November 10, 1922...... Office of Curator, Historical Department. December 15, 1922...... Office of Curator, Historical Department. January 12, 1923........ Office of Curator, Historical Department. February 9, 1923....... Portrait Gallery, Historical Department. March 9, 1923........ Office of Curator, Historical Department. A pril 13, 1923......... Office of Curator, Historical Department. May 11, 1923.......... Office of Secretary Executive Council-With Executive Council.

June $8,1923 \ldots \ldots \ldots$. Office of Secretary Executive Council-With Executive Council.

Total number meetings without Executive Council..........52

Total number meetings with Executive Council............. 7

Total ...............................

\section{VALUE OF THE BURLINGTON HAWKEYE FILES}

In the preparation of his article in this number of the AnNals on "Iowa Political Conventions and Platforms," Mr. Mott had all but despaired of locating a copy of the Iowa Whig platform of 1840 when, by persistence, he learned that it existed complete in the Burlington Hazckeye for August 6, 1840. Appealing to the present owners for its use Mr. John F. D. Aué, publisher, in appropriate refusal of our request to lend us the volume of 1840, wrote: "We also discover that the year 1840 is part of 
Copyright of Annals of Iowa is the property of State of Iowa, by \& through the State Historical Society of Iowa and its content may not be copied or emailed to multiple sites or posted to a listserv without the copyright holder's express written permission. However, users may print, download, or email articles for individual use. 